\title{
First record of Stephensoniana trivandrana Aiyer, 1926 (Oligochaeta: Naididae), in southeastern Brazil
}

\author{
D. A. Girolli * (D), G. R. Gorni ${ }^{a}$ (D), V. Colombo-Corbi ${ }^{a}$ (D) and J. J. Corbi ${ }^{b}$ \\ aPrograma de Pós-graduação em Desenvolvimento Territorial e Meio Ambiente, Universidade de Araraquara - UNIARA, \\ R. Carlos Gomes, 1338, Centro, CEP 14801-340, Araraquara, SP, Brasil

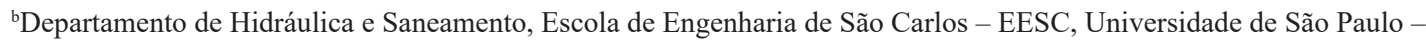 \\ USP, Av. Trabalhador são-carlense, 400, Parque Arnold Schimidt, CP 359, CEP 13566-590, São Carlos, SP, Brasil \\ *e-mail: douglasgirolli@gmail.com
}

Received: September 18, 2018 - Accepted: December 6, 2018 - Distributed: February 28, 2020

(With 1 figure)

Oligochaeta (Annelida: Clitellata) are recognized as highly diverse groups inhabiting a wide variety of aquatic ecological habitats. Due to their sensitivity to pollution (Rodriguez and Reynoldson, 2011; Tixier et al., 2011), these groups are used as a valuable tool in biomonitoring programs for water quality (Prygiel et al., 2000; Lafont et al., 2012; Vivien et al., 2014). These organisms can be found living on sandy and clay substrates, or in environments enriched by organic matter (Dornfeld et al., 2006). In addition, these worms are also associated with other substrates such as: bryophytes, bryozoans, hydrozoans (Corbi et al., 2005; Gorni and Alves, 2007), sponges (Gorni and Alves, 2008), insects (Corbi et al., 2004), gastropods (Gorni and Alves, 2006), and aquatic macrophytes (Correia and
Trivinho-Strixino, 1998; Trivinho-Strixino et al., 2000; Alves and Gorni, 2007).

In this article, we report the first occurrence of Stephensoniana trivandrana Aiyer, 1926 (Figure 1), in aquatic ecosystems of southeastern Brazil.

The specimens were identified in sediment samples collected in $07 / 30 / 2014$ in the deep $( \pm 21 \mathrm{~m})$ region of the Promissão Reservoir (21 $18^{\prime} 49^{\prime}$ 'S and 49 45'49'W). The Ekman-Birge grab $\left(0.0231 \mathrm{~m}^{2}\right)$ was used for the samples. All sampling and fixing procedures followed the protocol stipulated by Technical Standard CETESB L5.309 (CETESB, 2003). These collections were carried out by the Aquatic Communities Sector (ELHC) of CETESB and are part of the Sediment Quality Monitoring Network Project.

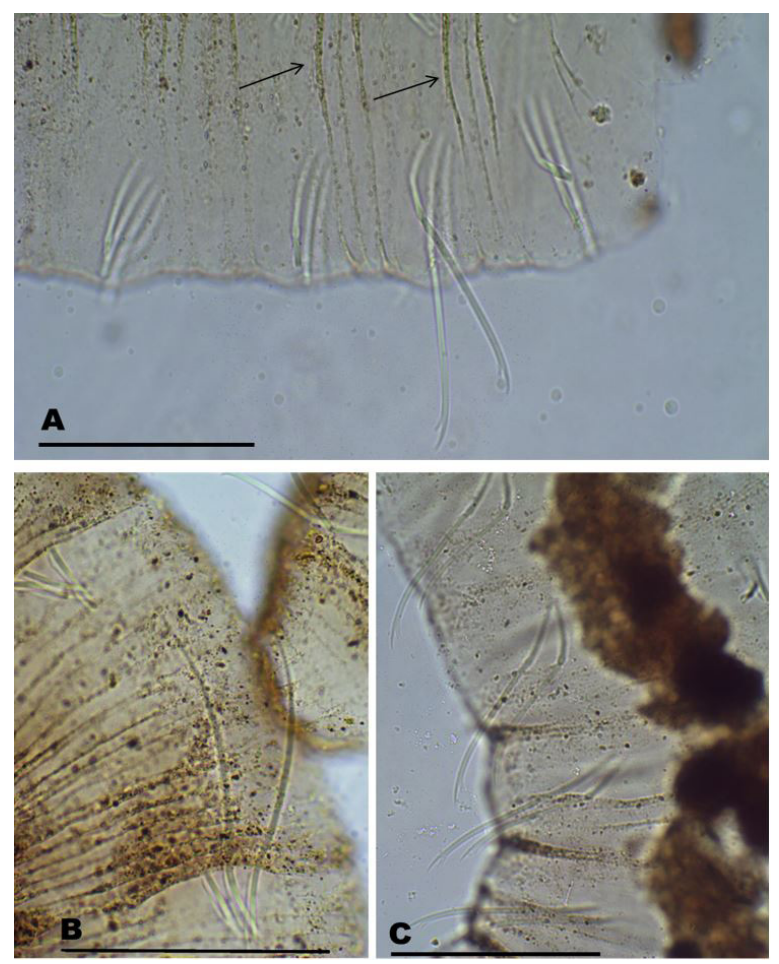

Figure 1. Stenphensoniana trivandrana. (A) Prostomium, anterior ventral chaetae (detail) and papillae (arrows); (B) Dorsal chaetae (detail); and (C) Posterior ventral chaetae. Scale bars: $100 \mu \mathrm{m}$. 
The species was identified using the taxonomic criteria adopted by Brinkhurst and Jamieson (1971) and Brinkhurst and Marchese (1989). According to these authors, $S$. trivandrana is described with the following characteristics: length: $2-6 \mathrm{~mm}$, segments $=21-43$. The body wall was covered by material adhered to the cutaneous glands. Dorsal bristle bundles containing 3-4 capillaries and 3-4 acicular; up to 4 ventral setae per bundle anteriorly, decreasing to 1 posteriorly, all with proximal nodules and distal tooth longer than the proximal. The difference between the teeth becomes more pronounced in the later segments. Pharynx in segment II / III; Sudden dilation of the intestine in segment VI. Clitelo in segments 1 / 2IV-1 / 2VI; deferens vessels apparently devoid of prostate, with thick and glandular epithelium, opening directly to the outside; 4-5 penile bristles with bundle, with distal nodule and two short and blunt teeth.

The S. trivandrana specie belongs to family Naididae, sub family Naidinae (Timm, 2009). Until the present study, records of $S$. trivandrana, in Brazil, were limited to only three states: Mato Grosso (Marchese et al., 2005), Mato Grosso do Sul (Takeda et al., 2000) and Paraná (Montanholi-Martins and Takeda, 1999; Behrend et al. 2009; Moretto et al., 2013). In previous studies in Southeastern Brazil, S. trivandrana had not yet been registered. This fact, associated with the unique characteristics of Brazilian continental ecosystems, justifies the realization of further research which aims to map oligochaete species in these environments, since these worms are considered important bioindicators of water quality and sediment.

\section{Acknowledgements}

We are thankful to teacher Mercedes Marchese to aid in the identification process. We are also grateful to the Water Communities Sector (ELHC) of the Environmental Company of the State of São Paulo - CETESB, especially to the biologists Monica Luisa Kuhlmann and Hélio Rubens Victorino Imbimbo for the authorization of access to the Oligochaeta Collection of Monitoring Network, and to the Coordination for the Improvement of Higher Education Personnel (CAPES) and National Foundation for the Development of Private Higher Education (FUNADESP) for financial support.

\section{References}

ALVES, R.G. and GORNI, G.R., 2007. Naididae species (Oligochaeta) associated with submersed aquatic macrophytes in two reservoirs (São Paulo, Brazil). Acta Limnologica Brasiliensia, vol. 19 , no. 4, pp. 407-413.

BEHREND, R.D.L., FERNANDES, S.E.P., FUJITA, D.S. and TAKEDA, A.M., 2009. Eight years of monitoring aquatic Oligochaeta from the Baía and Ivinhema Rivers. Brazilian Journal of Biology = Revista Brasileira de Biologia, vol. 69, no. 2, suppl., pp. 559-571. http://dx.doi.org/10.1590/S1519-69842009000300011. PMid:19738963.
BRINKHURST, R.O. and JAMIESON, B.G.M., 1971. Aquatic Oligochaeta of the world. 2nd ed. Toronto: University of Toronto Press, $860 \mathrm{p}$.

BRINKHURST, R.O. and MARCHESE, M.R., 1989. Guia para la identificación de oligoquetos acuáticos continentales de Sudy Centroamerica. Santa Fé: Asociación de Ciencias Naturales del Litoral, $179 \mathrm{p}$.

COMPANHIA AMBIENTAL DO ESTADO DE SÃO PAULO CETESB, 2003. L5.309, 2003. Determinação de bentos de água doce - macroinvertebrados: métodos qualitativo e quantitative [online]. [viewed 27 Sep 2017]. Available from: http://cetesb. sp.gov.br/normas-tecnicas-cetesb/normas-tecnicas-vigentes

CORBI, J.J., JANCSO, M.A., TRIVINHO-STRIXINO, S. and FRAGOSO, E.N., 2004. Occurrence of Oligochaeta living on larvae of Odonata from Ipeúna (São Paulo State, Brazil). Biota Neotropica, vol. 4, no. 2, pp. 1-3. http://dx.doi.org/10.1590/ S1676-06032004000200017.

CORBI, J.J., ROQUE, F.O., TRIVINHO-STRIXINO, S. and ALVES, R.G., 2005. Records of oligochaetes in freshwater sponges, on bryozoans, and on colonial hydrozoans from Brazil. Brazilian Journal of Biology $=$ Revista Brasileira de Biologia, vol. 65, no. 1, pp. 1-2. http://dx.doi.org/10.1590/S1519-69842005000100022. PMid:16025917.

CORREIA, L.C.S. and TRIVINHO-STRIXINO, S., 1998. Macroinvertebrados da Rizosfera de Scirpus cubensis na lagoa do Infernão (Estação Ecológica de Jataí - SP): estrutura e função. Acta Limnologica Brasiliensia, vol. 10, no. 1, pp. 37-47.

DORNFELD, C.B., ALVES, R.G., LEITE, M.A. and ESPÍNDOLA, E.L.G., 2006. Oligochaeta in eutroic reservoir: the case of Salto Grande reservoir and their main afluent (Americana, São Paulo, Brazil). Acta Limnologica Brasiliensia, vol. 18, no. 2, pp. 189-197.

GORNI, G.R. and ALVES, R.G., 2006. Naididae (Annelida, Oligochaeta) associated with Pomacea bridgesii (Reeve) (Gastropoda, Ampullaridae). Revista Brasileira de Zoologia, vol. 23, no. 4, pp. 1059-1061. http://dx.doi.org/10.1590/S010181752006000400011 .

GORNI, G.R. and ALVES, R.G., 2007. Naididae (Annelida, Oligochaeta) associated with briophytes in Brotas, State of São Paulo, Brazil. Revista Brasileira de Zoologia, vol. 24, no. 2, pp. 518-519. http://dx.doi.org/10.1590/S0101-81752007000200036.

GORNI, G.R. and ALVES, R.G., 2008. Naididae species (Annelida: Oligochaeta) associated with the sponge Metania spinata (Carter, 1881) (Porifera: Metaniidae) from a southeastern reservoir. Acta Limnologica Brasiliensia, vol. 20, no. 3, pp. 261-263.

LAFONT, M., TIXIER, G., MARSALEK, J., JÉZÉQUEL, C., BREIL, P. and SCHMITT, L., 2012. From research to operational biomonitoring of freshwaters: a suggested conceptual framework and practical solutions. Ecohydrology \& Hydrobiology, vol. 12, no. 1, pp. 9-20. http://dx.doi.org/10.2478/v10104-012-0004-4.

MARCHESE, M.R., WANTZEN, K.M. and DE DRAGO, I.E. 2005. Benthic invertebrate assemblages and species diversity patterns of the Upper Paraguay River. River Research and Applications 21(5), 485-499. http://dx.doi.org/10.1002/rra.814.

MONTANHOLI-MARTINS, M.C. and TAKEDA, A.M., 1999. Communities of benthic oligochaetes in relation to sediment structure in the Upper Paraná River, Brazil. Studies on Neotropical Fauna and Environment, vol. 34, no. 3, pp. 52-58. http://dx.doi. org/10.1076/snfe.34.3.52.8899. 
MORETTO, Y., SIMÕES, N.R., BENEDITO, E. and HIGUTI, J., 2013. Effect of trophic status and sediment particle size on diversity and abundance of aquatic Oligochaeta (Annelida) in neotropical reservoirs. Annales de Limnologie - International. Journal of Limnology, vol. 49, no. 1, pp. 65-78. http://dx.doi. org/10.1051/limn/2013040.

PRYGIEL, J., ROSSO-DARMET, A., LAFONT, M., LESNIAK, C., DURBEC, A. and OUDDANE, B., 2000. Use of oligochaete communities for assessment of ecotoxicological risk in fine sediment of rivers and canals of the Artois-Picardie water basin (France). Hydrobiologia, vol. 410, pp. 25-37. http://dx.doi. org/10.1023/A:1003799224961.

RODRIGUEZ, P. and REYNOLDSON, T.B., 2011. The pollution biology of aquatic oligochaetes. USA: Ed. Springer Science. http://dx.doi.org/10.1007/978-94-007-1718-3.

TAKEDA, A.M., PEREIRA, M.C.F. and BARBOSA, F.A.R., 2000. Zoobenthos survey of the Pantanal, Mato Grosso do Sul, Brazil. Bulletin of Biological Assessment Enginee, vol. 18, no. 3, pp. 49-55.
TIMM, T., 2009. A guide to the freshwater Oligochaeta and Polychaeta of Northern and Central Europe. Lauterbornia, vol. 66, pp. 1-235.

TIXIER, G., LAFONT, M., GRAPENTINE, L., ROCHFORT, Q. and MARSALEK, J., 2011. Ecological risk assessment of urban storm water ponds: literature review and proposal of a new conceptual approach providing ecological quality goals and the associated bioassessment tools. Ecological Indicators, vol. 11, no. 6, pp. 1497-1506. http://dx.doi.org/10.1016/j.ecolind.2011.03.027.

TRIVINHO-STRIXINO, S., CORREIA, L.C.S. and SONODA, K., 2000. Phytophilous Chironomidae (Diptera) and other macroinvertebrates in the ox-bow Infernão lake (Jataí Ecological Station, Luiz Antônio, SP, Brazil). Brazilian Journal of Biology = Revista Brasileira de Biologia, vol. 60, no. 3, pp. 527-535. http:// dx.doi.org/10.1590/S0034-71082000000300018. PMid:11188879.

VIVIEN, R., TIXIER, G. and LAFONT, M., 2014. Use of oligochaete communities for assessing the quality of sediments in watercourses of the Geneva area (Switzerland) and Artois-Picardie basin (France): proposition of heavy metal toxicity thresholds. Ecohydrology \& Hydrobiology, v. 14, no. 2, pp. 142-151. http:// dx.doi.org/10.1016/j.ecohyd.2014.03.003. 